\title{
BEING A TEACHER IN DISTANCE EDUCATION: THE PERCEPTION OF STUDENTS IN BASIC EDUCATION DEGREE
}

\author{
Vânia Graça1 ${ }^{1}$, Paula Quadros-Flores ${ }^{1}$, Altina Ramos ${ }^{2}$ \\ ${ }^{1}$ Centre for Research and Innovation in Education (inED), School of Education, Polytechnic \\ of Porto (PORTUGAL) \\ ${ }^{2}$ Centre for Research in Education (CIEd), Institute of Education, University of Minho \\ (PORTUGAL)
}

\begin{abstract}
Change is the key word that defines the current world situation and has an impact on education. What perspective do students have to assume future teaching roles on possible changes of educational environments and teaching profile? This article is part of the IFITIC Project "Innovate with ICT in Initial Teacher Training to Promote Methodological Renewal in Pre-school Education and in the $1^{\text {st }}$ and $2^{\text {nd }}$ Cycles of Basic Education" and has involved 26 students of the Degree in Basic Education of a higher education institution, in Portugal. A qualitative methodology was chosen as the aim was to analyse the individual experiences of the trainee students. As far as data collection is concerned, a questionnaire survey was applied and for the analysis of open answers the technique of content analysis was used. The results answer the questions: a) What is it for you to be a teacher in the digital age? b) Imagine that at the present time you are a teacher and you have to work at a distance with your classes: What digital media would you use? What kind of activities would you propose to the students? How would you accompany the students' work? Would you involve families? The analysis of these answers reveals the students' vision of the teaching profession and also the potential and weaknesses of the students' knowledge, allowing a more effective intervention by higher education institutions.
\end{abstract}

Keywords: distance learning, educational environments, initial teacher training, teacher profile.

\section{INTRODUCTION}

We are witnessing a time of change and unpredictability in society and education. This situation implies changes in the roles of the student and the teacher and opens new paths for more active methodologies in the teaching and learning process. The teacher has a new look at his or her practice, ceases to be the holder of knowledge and becomes the mediator, advisor and challenger of knowledge [19], [10], [31]. Based on constructivist theories, active methodologies emerge with the purpose of understanding learning and teaching as inseparable interactive processes, adjusted to the student at each moment of learning [8]. The teacher becomes a manager of collective and individual paths, unpredictable in an open, creative and enterprising construction [11]. The student, on the other hand, assumes a more active, intervening and autonomous role in the construction of his or her learning (Fig. 1).

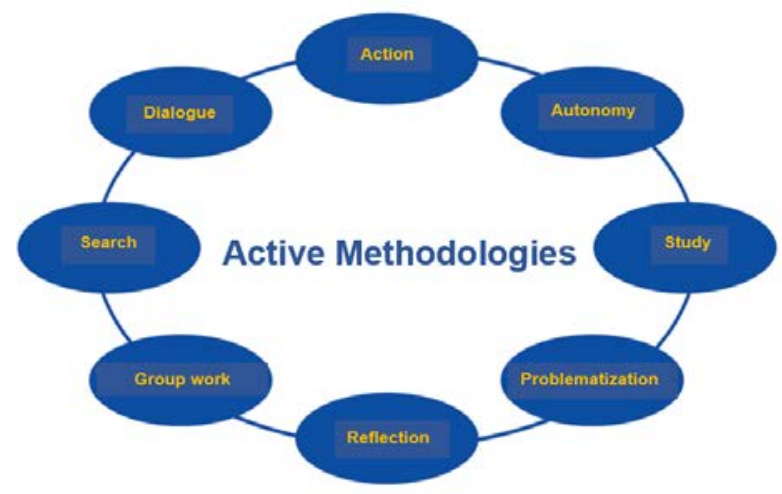

Figure 1. Characteristics of active methodologies [4].

[4] portrays the characteristics of active methodologies in a permanent cycle. In this sense, it refers to the beginning with a study of a theme or topic that may or may not start from the student, but that 
challenges him/her by actively involving him/her in the learning process. Thus, the problematisation arises from a starting question, which after being reflected leads to the research, usually in a group, as the purpose of answering the initial question. In this process of searching and selecting information, the student will have to dialogue with colleagues and critically reflect the content under study, which enhances a more active and autonomous role in their learning. In line with the above, are the innovative educational environments that arise within the ITEC Project 'Innovative Technologies for Engaging Classrooms', known as the "Classroom of the Future" that divides the learning space into 6 learning zones, namely: Interact, Present, Research, Create, Develop and Share [20].

There are several active methodologies: Gamification, Project Based Learning, Problem Based Learning, Peer Instruction, Flipped Classroom, Just-in-Time Teaching, Design thinking...[4]. This is the framework of the pedagogical approach "Made by them to them: The Students in the Learning Process" [22], created with the aim of combining three important steps in the learning process: the Flipped Classroom in the "prepare-todo" and the Storytelling in the "make-count" that together form the triad "see-reflect-evaluate". Recent researches show some studies on the use of active methodologies for the teaching of Portuguese [21], for the area of History with the Classroom reversed [5], [6], [13], [16]; for the teaching of Mathematics [29]; for distance learning [28].

In this sense, the integration of digital technologies in didactic pathways based on active methodologies becomes an appropriate and challenging strategy to change paradigms in teaching and learning. There is a variety of studies that reinforce the potential of the use of integrated digital technologies in educational environments for the motivation, production and exchange of knowledge, seeking solutions to the proposed problems [1], namely for areas such as History, which used Web 2.0 tools [27]; Mathematics, through the use of the mathematical TPACK model, Sciences, using data collection and processing tools, multimedia software, information systems, text editing and presentation tools, technology for projection [30]. However, the effective integration of ICT in teaching and learning processes by the teacher requires the development of digital skills and pedagogical knowledge of ICT use, within the framework of initial teacher training, which will resize the teaching profession with new traits that will redefine the school in a new era [23]. Several researchers have developed research focused on initial teacher training and ICT integration [9], [15], [17], [24].

This article is part of the IFITIC Project "Innovate with ICT in Initial Teacher Training to Promote Methodological Renewal in Pre-school Education and in the $1^{\text {st }}$ and $2^{\text {nd }}$ Cycles of Basic Education". It aims to rethink the educational practice with ICT in the initial training of future teachers in order to promote methodological renewal in Pre-school Education and in the $1^{\text {st }}$ and $2^{\text {nd }}$ Cycles of Basic Education. Therefore, we wanted to know the thinking of future teachers regarding the profile, methodologies and digital resources of the teacher in the digital age and the methodological options and digital resources that would be used if they developed their practices by distance teaching.

\section{METHODOLOGY}

In this study, a qualitative methodology was used in order to understand the phenomena, exploring them from the perspective of the participants in a natural environment and in relation to their context [26]. We tried to answer the following questions: a) What is it for you to be a teacher in the digital age? b) Imagine that at the present time you are a teacher and you have to work at a distance with your classes: What digital media would you use? What kind of activities would you propose to the students? How would you accompany the students' work? Would you involve families? At the end of the school year, a questionnaire survey was applied to 26 students of the Degree in Basic Education, with the aim of collecting their thoughts and opinions on the subject under study [25]. The sample attended the $3^{\text {rd }}$ year of the course, which did not include Supervised Pedagogical Practice (moment of intervention in an educational context), but which have only an elementary intervention.

The survey had four open questions: 1) What is it for you to be a teacher in the digital age? Justify your answer with theories, methodologies and digital media that you know of; 2) What do you think is the implication of educational environments in learning? 3) Do you think the technology to which we all have access helps or hinders the development of critical thinking? Give some examples; and 4) Imagine that at this moment you are a teacher and you have to work at a distance with your classes: What digital media would you use? What kind of activities would you propose to the students? How would you accompany the students' work? Would you involve families? Justify it. In this article, we focus only on students' conceptions in initial teacher training regarding what they understand by being a teacher in the digital age and understand, through an empathy exercise, their ideas and attitudes 
that they would have if they took on the role of a teacher working from a distance, identifying the digital media that would be used, the activities that would be proposed and the follow-up given to them.

The analysis of the replies was carried out using content analysis techniques, in which the data were initially codified and then categorised, i.e. the data were classified according to previously defined criteria [12]. In line with the same author's thought, the categorisation integrates two inverse processes: on the one hand, a procedure by "boxes" in which there is a pre-defined system of categories in the literature, and they are best divided into the various elements that are found during the analysis; on the other hand, a procedure by "mile" in which the categories of analysis are created as the data are analysed, and therefore the title of each category is only defined at the end of the operation. In the case of this analysis, the "mile" procedure was chosen, since the name of each category was only defined during the process.

In accordance with the above analysis techniques, three categories could be identified (Table 1).

Table 1- Categories and subcategories of analysis.

\begin{tabular}{|l|l|l|}
\hline \multicolumn{1}{|c|}{ Categories } & \multicolumn{1}{c|}{ Subcategories } & \multicolumn{1}{c|}{ Analysis descriptors } \\
\hline $\begin{array}{l}\text { A- Being a } \\
\text { teacher in the } \\
\text { digital age }\end{array}$ & A.1- Attitudes, postures & $\begin{array}{l}\text { They refer to the attitudes and attitudes that the digital age teacher } \\
\text { should have (adapting, innovating, creating, researching,...). }\end{array}$ \\
\cline { 2 - 3 } & $\begin{array}{l}\text { A.2- The integration of } \\
\text { new methodologies }\end{array}$ & $\begin{array}{l}\text { They refer to active methodologies that place the student as an } \\
\text { active agent in the construction of his/her knowledge. }\end{array}$ \\
\cline { 2 - 3 } & A.3- Digital resources & $\begin{array}{l}\text { They refer to the digital educational resources that the digital age } \\
\text { teacher should use. }\end{array}$ \\
\hline $\begin{array}{l}\text { B- Being a } \\
\text { teacher in } \\
\text { distance } \\
\text { education }\end{array}$ & $\begin{array}{l}\text { B.1- Strategies/ } \\
\text { Methodologies/ Activities }\end{array}$ & $\begin{array}{l}\text { They refer to the strategies, methodologies, activities that students } \\
\text { in initial teacher training would use in distance learning. }\end{array}$ \\
\cline { 2 - 3 } & B.2- Digital resources & $\begin{array}{l}\text { They refer to the digital educational resources that students in } \\
\text { initial teacher training would use in distance learning. }\end{array}$ \\
\cline { 2 - 3 } & $\begin{array}{l}\text { B.3- Monitoring student } \\
\text { learning }\end{array}$ & $\begin{array}{l}\text { They refer to the mechanisms for monitoring student learning that } \\
\text { students in initial teacher training would do in distance education. }\end{array}$ \\
\hline
\end{tabular}

\section{RESULTS}

It was sought to understand the conceptions of students in initial teacher training about what it is like to be a teacher in the digital age and what methodologies, strategies, activities and digital resources they would use if they were teachers working for distance learning, as well as monitoring their learning. The responses were analysed, codified and categorised, giving rise to two main categories and subcategories (Table 1).

\subsection{Being a teacher in the digital age}

Students in initial teacher training say that being a teacher in the digital age involves a set of attitudes/positions necessary for this time of change, requires the integration of renewed teaching and learning methodologies, as well as digital resources promoting knowledge, know-how, being and being fundamental to the transformations of today's world.

\subsubsection{Attitudes, postures}

With regard to the attitudes and postures that the teacher in the digital age must have, referred to by students in initial formation, they are mostly made explicit through verbs that in their conception are fundamental for the teacher to face the current and future challenges of a society in transformation. The following word cloud reflects the attitudes and postures most highlighted by future teachers (Fig. 1). In the word cloud, the size of the words is directly proportional to their frequency in the text. 


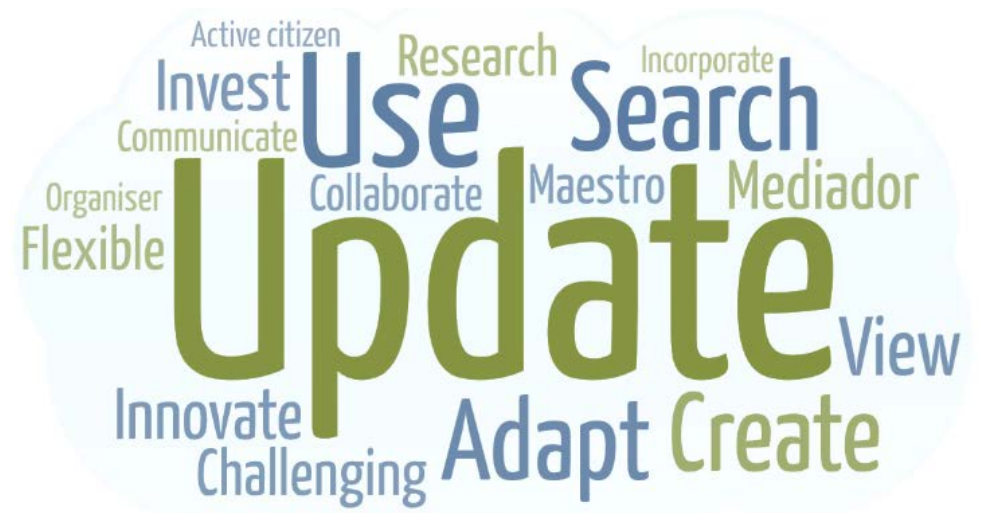

Figure 1. Cloud of words with the attitudes of the teacher in the digital age (own authorship).

We have noticed that the words Update, Adapt, Use, Create, Search and Innovate are the most evident verbs in the responses of students in initial training, are thus events represented in time, as a fundamental action of being a teacher in the digital age. Updating and adapting to new methodologies and digital resources in order to renew their educational practices: "Bearing in mind that children are already born in contact with such technologies, it becomes important for the teacher to adapt his or her methodologies so that his or her students can use these same technologies in an appropriate and useful way". [110]; "For me, to be a teacher in the digital age is to be an up-to-date teacher, interested, attentive and open to new theories and methodologies". 114]; "Times change and it is necessary for teachers to be able and able to keep up with this change and development, thus becoming a teacher in the digital age (...)" [116]. To use, appears together with technologies, i.e., to use technologies, which leads us to a recognition by them of the important role of ICTs in the digital society, namely in the educational process of students as pedagogically integrated they promote more meaningful learning and develop essential skills [18].

Creating, researching and innovating, were also actions that were very highlighted in the students' words: "Thus our citizenship has gone digital and the teacher has then to use the methodologies to stimulate research and research; communicate and collaborate; create and innovate". [11]; "(...) create our own resources and allow children to raise theirs independently". [111]. This shows that these students already understand the need for a renewed profession in their functions and ways of being pedagogical, giving opportunities to children to develop autonomously, critically, creatively and communicatively with others, through research, creation and collaboration, sharing. This requires intellectual capacity for learning and development, which currently places teachers at the centre of the "new pedagogy" as [14] states, or of the "educational limelight" as [3] reinforces. This framework raises the responsibility of initial teacher training towards quality training.

It should be noted that students also mention adjectives that characterise the teacher in the digital age, as challenging "The teacher must therefore be a challenger of his students' curiosity and autonomy, accompanying their work at all times". [19], mediator "In my opinion, a teacher in the digital age is undoubtedly an active facilitator of learning environments, he will be a mediator between the student and knowledge". [112], adjectives that reveal that these students already understand the role of the teacher in context, revealing more active methodologies in the teaching and learning process, creating opportunities for personal development and construction of knowledge in action, and in which the teacher is also the mediator of learning [10], [19], [31].

\subsubsection{The integration of new methodologies}

The responses from students in initial teacher training also showed that the teacher in the digital age must use new methodologies, namely active, based on constructivist theories of Vygotsky's learning. The word cloud reflects the words and expressions most mentioned by students (Fig. 2). 


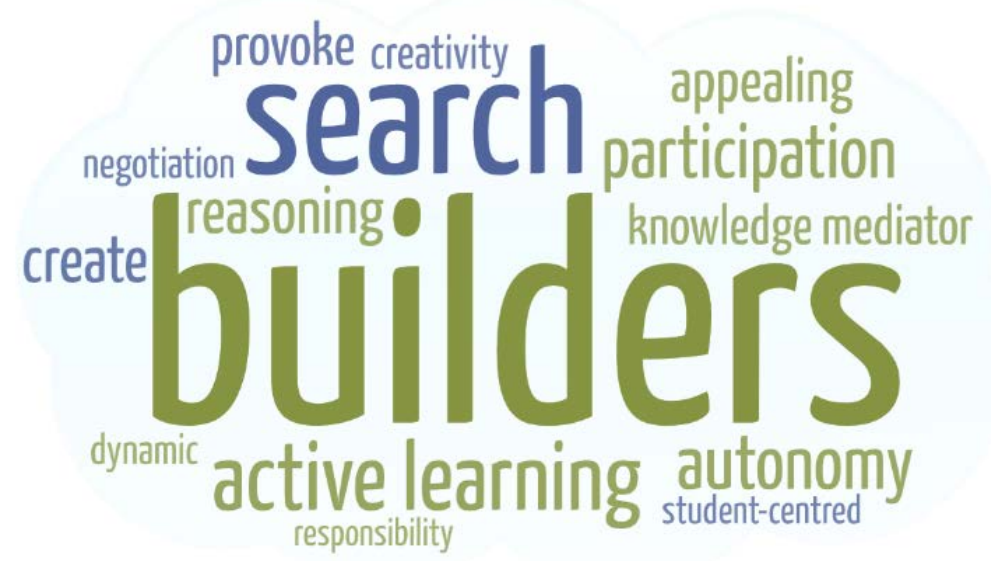

Figure 2. A cloud of words characterising methodologies of the new digital age (own authorship).

From the students' answers, the most mentioned words characterising new methodologies: "builders", "research", "active learning", "autonomy" and "creating". They reveal strong points in the student's action and also consequences in his personal maturity, contradicting the mechanical and memoristic process of a more traditional paradigm. Perhaps we can assess that, in their conceptions, the teacher of the $21^{\text {st }}$ century must develop educational proposals in which the students are builders and creators of their knowledge, through research that leads the student to interact with the content he is learning, researching, questioning, systematising and mobilising it in new learning [31] and consequently leading to active, autonomous and emotional learning [22], which shows that these students already understand the new paradigm of education.

\subsubsection{Digital resources}

We wanted to understand the digital resources that students in initial training consider relevant in educational practice (Fig. 3).

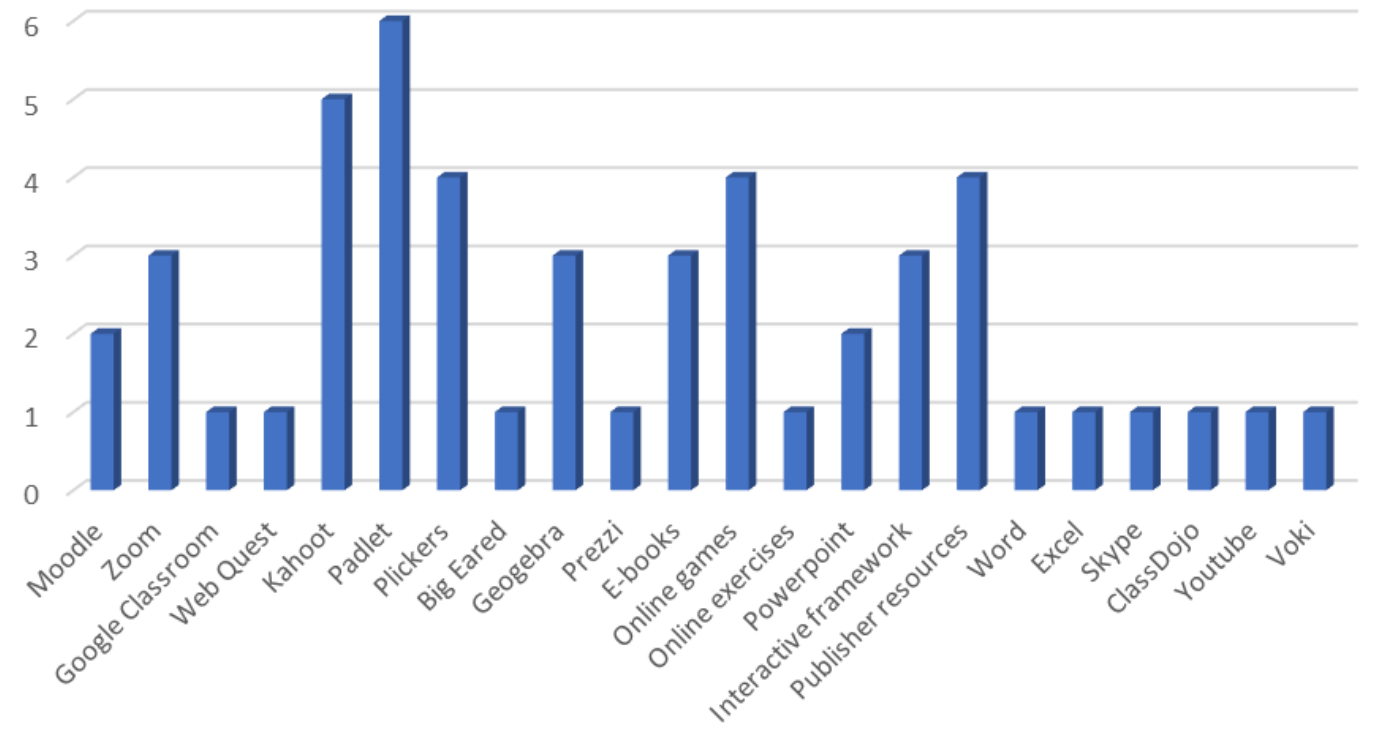

Figure 3. Students' views on the teacher's digital resources in the digital age (own authorship).

Although not very expressive, students in initial teacher training highlight interactive resources, promoters of a process that is above all collaborative, playful, gambling and stimulating challenges in the conquest of knowledge. Resources focused on student action. Thus, with clear predominance the Padlet $(23,1 \%)$ that allows the realization of virtual boards of organization; in the context of gamification Kahoot $(19,2 \%)$ and Plickers $(15,3 \%)$; of quick access, refer to the resources of publishers $(15,3 \%)$, more specifically the Virtual School (Escola Virtual) of Leya Education (Leya Educação) and the Digital Classroom (Aula Digital) of Porto Editora. The following are also to be mentioned: the videoconference zoom platform (11,5\%), Geogebra $(11,5 \%)$ for teaching Mathematics, 
the creation of E-books (11.5\%), the interactive whiteboard $(11,5 \%)$, the creation of a b-learning environment such as Moodle (7,6\%), and the Office Powerpoint tool (7,6\%). It should be noted that students already possess knowledge of digital resources that reflect different educational intentions, which pedagogically integrated into didactic pathways enhance the construction of active, participatory, autonomous and innovative learning [22].

\subsection{Being a teacher in distance education}

We were interested to hear the opinions of students in initial teacher training about being a teacher in a distance learning situation. The responses revealed some strategies, methodologies, activities and digital resources that would be mobilised if they developed distance learning practices, as well as the role attributed to parents in this type of teaching.

\subsubsection{Strategies/Methodologies/Activities}

We asked students in initial teacher training to imagine themselves in a distance learning situation and we questioned them: What kind of activities would you propose to the students? (Fig. 4).

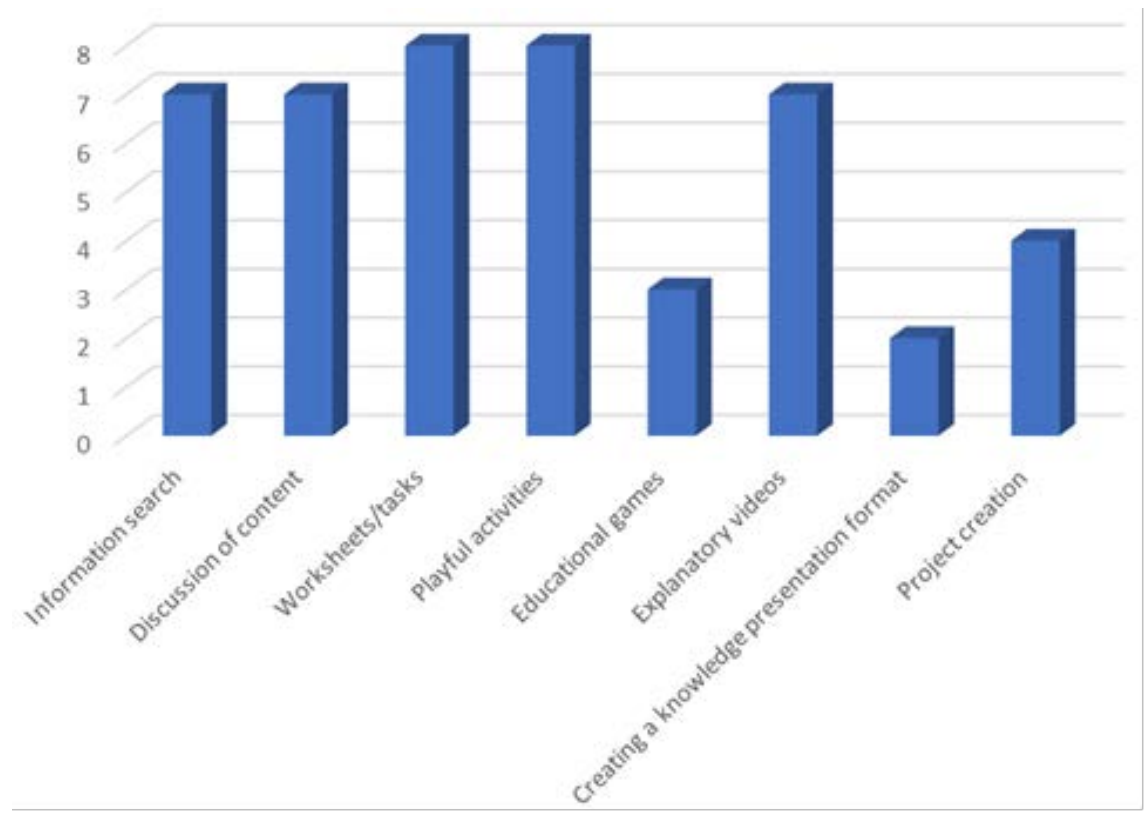

Figure 4. Proposals from distance learning students (own authorship).

Although the answers are not very expressive, they are more the proposals for the realization of Worksheets/tasks $(30,7 \%)$ and playful activities $(30,7 \%)$. This result reflects, on the one hand, that some students in Basic Education are still learning, so influenced by pedagogies with which they have learned, but are already aware of the importance of playfulness in the learning process. On the other hand, the results reinforce the importance of attending the vocational master as an academic level that makes it effectively capable for the profession "It would provide students with playful and interesting activities, so that they would be willing to continue working. It would accompany students through activities with deadlines". [115]; "Being going through a period when the work has to be done at a distance, I tried not to lose the focus of my students, encouraging them with activities, tasks, proposals". [18].

Note that some students reported that the activities would be carried out using digital platforms "I would then ask the students to perform some tasks, both from the manual and from other platforms that I think would be appropriate". [15]. Then "Information research" (26,9\%) "The proposed activities could be in the context of script oriented research, requesting the help of an adult, for example, but also (and especially in the first cycle) for consolidation" [122]; Content discussion "(...) so that students put their ideas and opinions (...)" (26,9\%), Explanatory videos $(26,9 \%)$ "Now, using explanatory videos" [I26]. The strategies, methodologies and activities mentioned by the students show that some students already know resources that respond to distance learning and record other ways of teaching adjusted to a transition of methodologies, from traditional to more active methodologies. This shows 
that the training school has responded in teaching technological and methodological possibilities, although the creative capacity of their use depends on the capacity of each student.

\subsubsection{Digital resources}

When asked about the digital resources they would use if they were teachers in distance learning, students in initial teacher training mentioned several (Fig. 5).

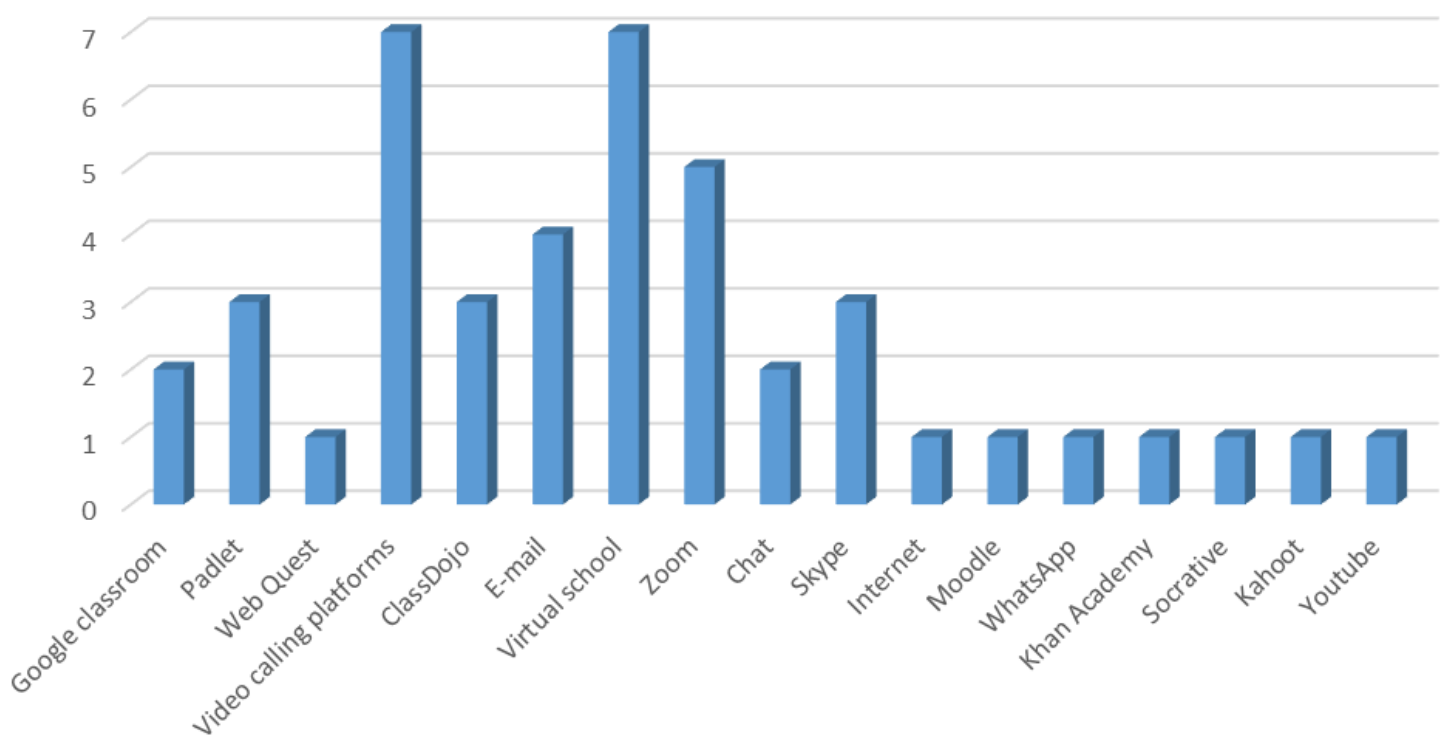

Figure 5. Students' views on the digital resources used in distance learning (own authorship).

The diversity of resources shows that they are knowledgeable about various resources that answer the question of distance learning. With clear predominance, students reveal themselves to select Video Call Platforms and the (Escola Virtual) (26,9\%). This type of resources allows synchronous and asynchronous classes, but also immediate access to learning resources built by the publisher. These students mention some platforms in their speech: $(19,2 \%)$ mentions the zoom "Currently, with the COVID_19 virus pandemic I am experiencing for the first time distance learning classes and the resources that are being shown now, such as zoom". [117] and Skype (11,5\%) "For this, I would ask that, using Skype, they connect students to the Platform". [15]. As for resources in publishing platforms, they refer to the Virtual School (Escola Virtual) and the Digital Classroom (Aula Digital) of Leya Educação Publishing House, where they find thousands of tests, interactive classes and other materials, from $1^{\text {st }}$ to $12^{\text {th }}$ years, to train and test their knowledge, developing essential skills of reasoning, critical thinking, autonomy and creativity and becoming competent, confident and successful citizens. There is also an attempt to integrate the use of cognitive tools in educational practices [7] that lead to the development of complex thinking, such as Padlet (11,5\%) and ClassDojo $(11,5 \%)$ in the construction of interactive murals; for gamification activities, Kahoot $(3,8 \%)$ and Socrative $(3,8 \%)$; and Youtube $(3,8 \%)$ in video viewing.

\subsubsection{Monitoring student learning}

To the question "Imagine that at the present time you are a teacher and you have to work at a distance with your classes: how did you follow the students' work? Did you involve families?", the answers were unanimous regarding the importance of involving families in this type of teaching, and the activities proposed to accompany the students' work are depicted in figure 6. 


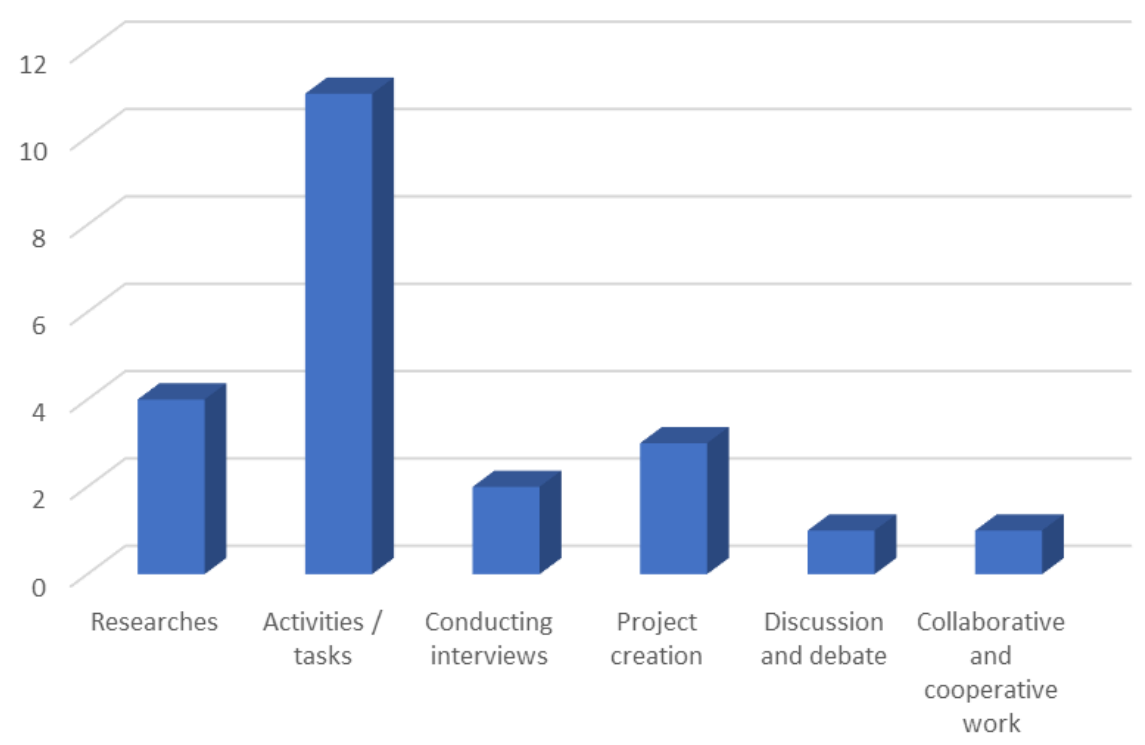

Figure 6. Students' opinions regarding the monitoring of students in distance learning situations (own authorship).

Students in initial training are already aware of the importance of the family in the learning process of their students and the way they respond better in accompanying their children, perhaps for this reason they state more clearly that they would accompany the students through Activities/tasks (42,3\%). However, they refer to other more creative practices, such as research, a playful environment, and Project methodology: "In this particular case of social isolation in which we currently live, I would try to involve families through playful activities or research." [19], "(...) and it would be up to the families to help the children and make this activity received and understood by the child". [111]; of research on school content $(15,3 \%)$ "This would be guided by a script provided by me and supervised by the parents (I would start by involving families here, I would ask them to supervise the research to ensure that the information collected was reliable)". [13]. They also involved the families by setting up a project $(15,3 \%)$, but they don't explain what it consists of "(...) I would use this time to set up a project and thus involve the parents completely in everything we were going to learn together, because that's the only way we could do it". [12]. The integration of projects in distance learning environments is fundamental for an articulated and meaningful learning, because the project starts from the children and is developed by them, which shows that these students also have some pertinent ideas of orientation in online space. These answers reinforce that some students are already aware of the limits and potentialities of the family in the educational process, but also the importance of playfulness and project-based learning in educational success.

\section{CONCLUSIONS}

The results reveal knowledge already acquired by students who, for the most part, wish to become teachers in the future. This knowledge animates the perspective of a new educational paradigm, whose change is found in the teacher's design and in the way he or she acts in the teaching process. The results also reveal that they are at a stage of development, highlighting here the Master's degree as an important stage in the teaching profession. Initial training effectively assumes a unique responsibility in the training of future educators and teachers in the digital age. It is at this stage that there is room for them to experience new methodologies, different strategies and digital resources. Students in initial training consider that being a teacher in the digital age involves a set of attitudes, methodologies and digital resources aimed at active learner-centred methodologies. Finally, they assume that families would have a very important role in this type of teaching, assisting in activities/tasks, information research and project creation. Nowadays, it seems interesting to us to know the beliefs and conceptions of future teachers and the relationship with teaching practice, as [2] state. With this study we intend a reflection in the field of Initial Teacher Training. The results reveal that institutions have responded to change and that students in Basic Education already have concepts that reveal to be potential in building a challenging teaching profile of a new era in education. On the other hand, they reveal some fragility in the creation of new practices, which is normal because this creative competence is developed in students on internship. 


\section{ACKNOWLEDGEMENTS}

This work is financed by national funds through FCT - Foundation for Science and Technology, I.P., in the framework of the project UIDB/05198/2020 (Centre for Research and Innovation in Education, inED).

\section{REFERENCES}

[1] A. Gonçalves, O Papel das TIC na Escola, na Aprendizagem e na Educação. Dissertação de Mestrado em Comunicação, Cultura e Tecnologias da Informação, Lisboa: ISCTE-IUL, 2012. Retrieved from https://repositorio.iscte-iul.pt/handle/10071/5146

[2] A. Nóvoa and A. Bolívar, "Epistemologías Docentes", REDU. Revista de Docencia Universitaria, vol. 13, no. 1, pp. 17-19, 2015.

[3] A. Nóvoa, Professores: Imagens do futuro presente, Lisboa: Educa. Universidade de Lisboa, Instituto de Educação, 2009.

[4] A. Silva, Guia prático de metodologias ativas com uso de tecnologias digitais da informação e comunicação. Lavras: UFLA, 2020. ISBN: 978-65-86561-02-9.

[5] C. Almeida, "Possibilidades e limites de uma intervenção pedagógica pautada na metodologia da sala de aula invertida para os anos finais do ensino fundamental". Dissertação de Mestrado Profissional em Matemática em Rede Nacional, Brasil: Universidade Tecnológica Federal do Paraná, Pato Branco, 2017.

[6] C. Glufke, "Metodologias ativas no ensino de História: sala de aula invertida aplicada no Ensino Médio na Escola Marista de Santa Maria-RS". Dissertação de Mestrado Profissional em Ensino de História- ProfHistoria, Brasil: Universidade de Santa Maria, 2019.

[7] D. Jonassen, Computadores, Ferramentas Cognitivas. Desenvolver o pensamento crítico nas escolas. Porto: Porto Editora, 2007.

[8] F. Costa, "Desenvolvimento Curricular e TIC: Do déficit tecnológico ao déficit metodológico", in Atas do XIX colóquio da Secção Portuguesa da Afirse, pp. 159-171, 2012

[9] G. Fonseca, "As tecnologias de informação e comunicação na formação inicial de professores do $1^{\circ}$ ciclo do ensino básico - fatores constrangedores invocados pelos formadores para o uso das tecnologias". Educação \& Formação, vol. 4, no. 2, pp. 3-23, 2019.

[10] J. Moran, "Mudando a educação com metodologias ativas" Coleção Mídias Contemporâneas. Convergências Midiáticas, Educação e Cidadania: aproximações jovens, pp. 15-33, 2015.

[11] L. Bacich and J. Moran, Metodologias ativas para uma educação inovadora: uma abordagem teórico-prática. Porto Alegre: Penso, 2018.

[12] L. Bardin, Análise de conteúdo. Editora Edições 70, 1977.

[13] L. Santos and T. Tezani, "Aprendizagem colaborativa no ensino de História: a Sala de Aula Invertida como Metodologia Ativa", RENOTE, vol. 16, no. 2, pp. 101-111, 2018. Retrieved from https://doi.org/10.22456/1679-1916.89302

[14] M. Castells, The internet galaxy. Fundação Calouste Gulbenkian, 2004. ISBN: 9789723110654.

[15] M. Felizardo and F. Costa, "O que pensam os professores portugueses dos formadores e da formação efetuada pelos CFAE na área das TIC", Investigar Em Educação, vol. 6, no. 6, pp. 225244, 2017.

[16] M. Oliveira, "Metodologias Ativas no Ensino de História: um Caminho para o Desenvolvimento da Consciência Crítica", in Metodologia ativa na educação (A. Silva, P. Bieging and R. Busarello, eds.), São Paulo: Pimenta Cultural, 2017.

[17] M. Raposo-Rivas, P. Quadros-Flores, E. Martínez-Figueira, A. Pereira da Silva and F. TelladoGonzález, "Utilización de TIC para la innovación en el Prácticum”. Revista Practicum, vol. 5, no. 1, pp. 22-36, 2020. Retrieved from https://doi.org/10.24310/RevPracticumrep.v5i1.9814 
[18] M. Rapp, "Integração das TIC nos processos de ensino e aprendizagem pelos professores do $1^{\circ}$ e $2^{\circ}$ Ciclo de uma escola portuguesa", Dissertação de Mestrado em Educação, com Especialização em e-Learning e Tecnologias de Informação e Comunicação (TIC) em Educação, Lisboa: Faculdade de Ciências e Tecnologia da Universidade Nova de Lisboa.

[19] N. Berbel, "As metodologias ativas e a promoção da autonomia de estudantes.", Revista Semina: Ciências Sociais e Humanas, vol. 32, no. 1, pp. 25-40, 2011. Retrieved from http://dx.doi.org/10.5433/1679-0383.2011v32n1p25

[20] N. Pedro, "Ambientes educativos inovadores: o estudo do fator espaço nas 'Salas de Aula do Futuro' portuguesas, Revista Tempos e Espaços em Educação, São Cristóvão, Sergipe, Brasil, vol. 10, no. 23, pp. 99-108, 2017. Retrieved from http://dx.doi.org/10.20952/revtee.v10i23.7448, ISSN: 1983-6597.

[21] P. Lima, "O uso de metodologias ativas para o desenvolvimento de um projeto de multiletramentos em Lingua Portuguesa", Dissertação de Mestrado de Linguística Aplicada, Brasil: Departamento de Ciências Sociais e Letras, Pedagogia e Serviço Social Universidade de Taubaté.

[22] P. Quadros-Flores, A. Flores, A. Ramos, and A. Peres, "Made by them to them: The Students in the Learning Process.", in International Conference NEW PERSPECTIVES IN SCIENCE EDUCATION 8th Edition, pp. 417-423, Florence: Filodiritto Editor, 2019. Retrieved from 10.26352/D321_2420-9732.

[23] P. Quadros-Flores and M. Raposo-Rivas, "A inclusão de tecnologias digitais na educação: (re)construção da identidade profissional docente na prática" Revista Practicum, vol. 2, no. 2, pp. 2-17, 2017. Retrieved from https://doi.org/10.24310/revpracticumrep.v2i2.9855

[24] P. Quadros-Flores and A. Ramos, "Práticas com TIC potenciadoras de mudança", in 1. ${ }^{\circ}$ Encontro Internacional de Formação na Docência (INCTE), Bragança: Instituto Politécnico de Bragança, 2016, pp. 195-203. http://hdl.handle.net/10198/11435

[25] R. Ghiglione, and B. Matalon, O inquérito: teoria e prática. Oeiras: Celta Editora, 2001

[26] R. Sampieri, C. Collado and P. Baptista, Metodología de la Investigación. 6. ${ }^{\circ}$ Ed. México: McGRAW-HILL / Interamericana Editores, S.A. DE C.V, 2014. ISBN: 978-1-4562-2396-0

[27] S. Cruz, "Proposta de um Modelo de Integração das Tecnologias de Informação e comunicação nas Práticas Letivas: o aluno de consumidor crítico a produtor de informação online", Tese de Doutoramento em Ciências da Educação, na Especialidade de Tecnologia Educativa, Braga: Universidade do Minho, 2009.

[28] S. Fonseca, and J. Mattar, "Metodologias ativas aplicas à educação a distância: revisão da literatura." Revista EDaPECl, vol. 17, no. 2, pp. 185-197, 2017.

[29] T. Andreetti, "Gamificação de aulas de matemática por estudantes do oitavo ano do ensino fundamental", Dissertação de Mestrado em Ciências e em Matemática, Curitiba: Universidade Federal do Paraná, 2019.

[30] T. Martinho and L. Pombo, "Potencialidades das TIC no ensino das Ciências Naturais-um estudo de caso Title: Potentialities of ICT in Natural Sciences teaching-a case study." in Revista Electrónica de Enseñanza de las Ciencias, vol. 8, 2009.

[31] V. Graça, G. Solé and A. Ramos, "Inovação metodológica e tecnológica no ensino e aprendizagem da História" in Livro de atas da VI Conferência Ibérica de Inovação na Educação com TIC: ieTIC2020 (J.A. Moreira, A. García-Valcárcel, P. Gutiez Cuevas, and V. Gonçalves, eds.), Bragança: Instituto Politécnico, 2020). Retrieved from http://hdl.handle.net/10198/19663 